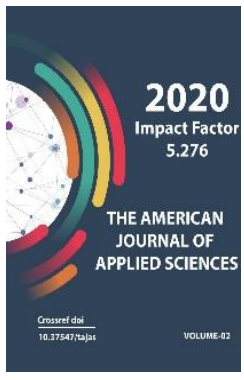

Journal Website: http://usajournalshub.c om/index,php/tajas

Copyright: Original content from this work may be used under the terms of the creative commons attributes 4.0 licence.

\section{The Results Of Using The Probiotic Feed Additive "Baktovit" In The Diet Of Rabbits}

Hidirov K.I

Center for Rabbit Breeding and Genetics, Uzbekistan

Rahimov A. T

Center for Rabbit Breeding and Genetics, Uzbekistan

Kutlieva G.J

Institute of Microbiology of the Academy of Sciences of the Republic of Uzbekistan

Nurmuhammedova D.K

Institute of Microbiology of the Academy of Sciences of the Republic of Uzbekistan

Yusubahmedov A.A.

National University of Uzbekistan named after Mirzo-Ulugbek, Uzbekistan

\title{
ABSTRACT
}

For the first time in the Republic of Uzbekistan the possibility of using the domestic probiotic feed additive "Baktovit" in the diet of rabbits was studied. The positive effect of the additive on the hematological parameters and the state of natural resistance of the rabbit organism was established. The use of the probiotic feed additive "Baktovit" will make it possible to participate in the state import substitution program and will contribute to a higher efficiency of vaccine-preventive and therapeutic measures.

\section{KEYWORDS}

Probiotics, veterinary medicine, zoo-technical, indicators, class, clinic, hematology, immunology.

\section{INTRODUCTION}

The creation of bacterial preparations based on microorganisms - representatives of the normal microflora of the host organism - for use in veterinary practice for therapeutic and prophylactic purposes is one of the modern directions of scientific and technological 
progress.These drugs, called probiotic, contain in their composition live microorganisms, which, as a rule, have valuable industrial characteristics and have a positive regulating direct effect on pathogenic and opportunistic microorganisms and indirectly - by activating specific and nonspecific defense systems of the host organism. Bacterial cells of a probiotic can be considered as biocatalysts of many vital processes in the digestive tract, producing a variety of enzymes and biologically active substances.

Currently, in animal husbandry, the prophylactic and therapeutic use of microorganisms is widespread, which are one or more active living cultures designed to restore and maintain beneficial microflora of the gastrointestinal tract (GIT) and at the same time do not pose a threat to the macroorganism.

Animals constantly experience the negative influence of pathogenic microflora entering the body with feed and water of poor sanitary and hygienic quality. Changes in the microflora of the gastrointestinal tract often occur as a result of various adverse effects: changes in diets, the composition of feed, violation of feeding regimes, the use of poor-quality feed. Changes in the normal microflora can also occur during and after antibiotic treatment, therefore, to restore normal flora, it is imperative to introduce probiotics $[1,2,3]$.

There is a lot of information in literature sources where it is indicated that the use of probiotics helps to optimize metabolic processes in the body of rabbits, efficacy, protein-amino acid status, morphological and biochemical parameters are highlighted when using various dietary supplements and probiotics [9, 11, 14, 15, 17, 18]. The Institute of Microbiology of the Academy of Sciences of the Republic of Uzbekistan has developed a biological active additive (BAD) "Baktovit", containing bacteria of the genera: Lactobacillus, Bifidobacterium, Propionibacterium and spore-forming bacteria - Bacillis subtilis, which are probiotics.

The purpose of the research: the research is to determine the zoo-technical feasibility and effectiveness of using the probiotic feed additive "Baktovit" in the diets of rabbits. Based on our goal, we have identified the tasks:

- To study the effect of the feed "Baktovit" on the weight gain of rabbits;

- To determine the effect of the probiotic feed additive "Baktovit" on some hematological parameters and the functional state of the natural resistance of the rabbit organism.

\section{METHODOLOGY}

To achieve the goal of the research and accomplish the assigned tasks, we conducted an experiment where we used 40 rabbits, which were divided into an experimental control group. To rabbits of the experimental group, the feed additive with an activity of 1x1010 CFU was dissolved in 100 liters of water and administered to rabbits using the nipple method, and the feed additive was not used in the control group of rabbits.

Research types: the study used general clinical hematological, zoo-technical and immunological methods.

\section{MATERIAL AND RESEARCH METHODS}

Joint research was carried out at the Center for Breeding and Genetics of Rabbit Breeding and at the Institute of Microbiology of the 
Academy of Sciences of the Republic of Uzbekistan. In the experiments, 30 rabbits were used, obtained from 5 families of the New Zealand breed. 32 -, received also 5 families of the Californian breed. The studies continued from one month of age to 70 days of age.

The clinical and physiological state of the rabbits was assessed by methods generally accepted in veterinary medicine; the weighing of the rabbits was carried out at 20 days of age, 30 and 60 days of age. Hematological studies were carried out, the activity in neutrophils of myeloperoxidase, cationic proteins and phagocytic activity were determined using a test with nitro blue tetrazolium (NBT test) according to the method of Gordienko G.I. and others. Moreover, blood serum for the content of circulating immune complexes; total protein and immunoglobulins have been investigated by conventional methods. A detailed blood test was used to study the content of hemoglobin, erythrocytes, platelets, leukocytes and other hematological parameters.

The obtained results were subjected to statistical processing using the standard Statistika for Windows software package according to the well-known methods of variation statistics with an assessment of the significance of the indicators $(M \pm m)$ and the

\begin{tabular}{|l|l|l|}
\hline Indicators & Control & Experimental \\
\hline Average live weight at birth & $49,42 \pm 0,7$ & $50,5 \pm 0,5$ \\
Average live weight at 20 days of age & $288,94 \pm 1,49$ & $402,31 \pm 0,53 * *$ \\
\hline
\end{tabular}

differences of the considered samples by the Student's t-test. Differences in the compared groups were considered significant at a significance level of $95 \%(p<0.05)$.

\section{RESULTS OF THE RESEARCH}

From the data presented in table 1, it can be seen that the average daily gain of the 2 and 3 experimental groups is more than the control group ( $p<0.01, p<0.001$ ) by 10 and $30 \%$, respectively.

Body weight by 60 days in experimental groups 1 and 2 was $2588 \pm 0.06(p<0.01)$ and $3060 \pm 0.04$ grams $(p<0.001)$, respectively, which was also higher than the control group by 10 and $30 \%$.

It should be noted that the consumption of PK by young rabbits from 2.5 months of age was higher than the OR of other groups of animals.

Thus, the use of a probiotic supplement to feed "Baktovit" when raising rabbits is accompanied by an increase in the average daily body weight gain.

Table 1 Indicators of raising rabbits when using the probiotic additive feed "Baktovit" 
Average live weight at 2 months of age

Average daily gain at 2 months of age

In\% to control up to 2 months of age

Average live weight at 3 months of age

In $\%$ to control

Average daily gain at 3 months age

In $\%$ to control up to 3 months of age

\begin{tabular}{l|l|}
$1319 \pm 0,024$ & $1829 \pm 0,06 * * *$ \\
$22,13 \pm 0,51$ & $29,84 \pm 0,93 * * *$ \\
100 & 135 \\
$2357 \pm 0,02$ & $3060 \pm 0,04 * * *$ \\
100 & 130 \\
$25,675 \pm 0,25$ & $33,29 \pm 0,37 * * *$ \\
100 & 130
\end{tabular}

$$
\text { Hereinafter:* - p }>0,05 ; * *-p<0,01 ; * * *-p<0,001
$$

Morphological parameters of blood. It is known that blood, together with lymph and tissue fluid, forms the internal environment of the body, washing all cells and tissues. By the composition of the blood, one can judge about many processes taking place in the body. The composition of the blood not only determines the state of the animal, but also gives a general idea of the adaptation to environmental conditions. The blood picture makes it possible to observe various changes that occur in the body of animals under the influence of feeding and maintenance, which makes it possible to assess their physiological state $[11,16]$.

Blood includes two parts of a liquid medium plasma and corpuscles suspended in it (platelets, erythrocytes and leukocytes). The content of formed elements can change dramatically in pathological conditions of the body [3]. In the first month of life, the number of erythrocytes in the blood is much lower than the norm, but with increasing age it rises and by 4 months of age comes into line with the norm [5].

The main part of red blood cells is hemoglobin, which provides the respiratory function of the blood, being a respiratory enzyme.

Leukocytes are the direct executors of immune responses. Their purpose is to recognize foreign substances and microorganisms, to combat them, and also to record information about them.

Lymphocytes are responsible for the formation of specific immunity and carry out immune surveillance in the body, preserve the genetic constancy of the internal environment. In the central organs of the immune system, the primary differentiation of the so-called zero lymphocytes is carried out with their transformation into T-lymphocytes (in the thymus), B-lymphocytes (in the bone marrow of mammals and in the bursa Fabricius in birds). In the peripheral organs of immunity, T-lymphocytes acquire the ability to 
carry out an immune response of the cellular type, and B-lymphocytes acquire a humoral response by producing antibodies [6].

Of the total number of lymphocytes circulating in the blood and lymph, approximately $75 \%$ are T-lymphocytes, $15 \%$ are B-lymphocytes, and 10\% are cells that do not belong to either group (null cells, or K-cells) [3].

The level of natural resistance determines the degree of resistance of animals to diseases and is directly dependent on age, season, feeding conditions and maintenance.

The results of laboratory analysis of hematological and immunological parameters are presented in Table 2.

In the blood of adult rabbits, the variation of leukocytes is considered normal in the range of 5.5-10 thousand in $1 \mathrm{~mm} 3$, erythrocytes - 4.77.5 million in $1 \mathrm{~mm} 3$, ESR $1.5 \mathrm{~mm} \mathrm{/} \mathrm{h,}$ hematocrit $35-45 \%$ [ 12].

The average indicators of leukocytes in the blood of the 2nd and 3rd experimental groups were within the physiological norm and were higher than the control by 52.3 ( $p>0.05)$ and $43.2 \%$.

The average indicators of erythrocytes and hemoglobin in the experimental groups were within the physiological norm and were higher than the control by 21.9 ( $p>0.05$ ) and $23.1 \%$ ( $p>0.05$ ) - erythrocytes and by 10.2 and 38, 2\% ( $p<0.001$ ) - hemoglobin, respectively, while the hemoglobin index in the control group was underestimated.
An increase in the number of erythrocytes has a positive effect on the development of the immune status [4].

Erythrocyte sedimentation (ESR) is the property of erythrocytes to settle at the bottom of the vessel while maintaining the blood in a non-clotting state. ESR is a nonspecific indicator of the state of blood in animals. The ESR value depends on many factors and primarily on the content of large molecular proteins in the blood plasma globulins. In experimental animals, the ESR value was within the physiological norm. ESR in rabbits of the control group was $2.33 \pm$ $0.333 \mathrm{~mm} / \mathrm{h}$ at a rate of $1-2 \mathrm{~mm} / \mathrm{h}$.

The hematocrit value - the volumetric ratio of the formed elements of blood and plasma, in experimental rabbits of the 2nd group was higher than the control by $5.6 \%$. In the third group, the hematocrit value was higher than the control by $43.5 \% \quad(p<0.001)$ and corresponded to the norm.

Phagocytic activity of leukocytes is the ability of phagocytes to capture, kill and digest pathogenic and opportunistic microorganisms. Phagocytic activity of neutrophils usually increases at the beginning of the development of the inflammatory process. A decrease in the phagocytic activity of blood cells contributes to the development of a chronic inflammatory process and the emergence of aggression against the body's own tissues (the emergence of autoimmune processes).

Phagocytic activity in rabbits of the second and third experimental groups was normal and higher than the control by 7.3 ( $p<0.01)$ and $13.7 \%$ ( $p>0.05)$. 
That is, the absorption index should be considered the most informative for assessing

phagocytic activity. Phagocytic number, coefficient of phagocytic number, which reflect the completeness of phagocytosis (CP) and bactericidal index is the ability of a phagocyte to digest a captured microbe [8].

Table 2. Hematological and immunological parameters

\begin{tabular}{|l|l|l|}
\hline Indicators & Control & Experiment \\
\hline Leukocytes (WBC), 109/l & \\
Erythrocytes (RBC), 1012/l & $5,17 \pm 0,857$ & $6,19 \pm 0,14^{*}$ \\
Hemoglobin (HCB), g/l & $5,027 \pm 0,438$ & $103,67 \pm 5,783^{* *}$ \\
Hematocrit (HCT), \% & $75 \pm 9,292$ & $33,2 \pm 0,418^{* * *}$ \\
Average erythrocyte volume (MCV), fl & $23,17 \pm 2,371$ & $60,33 \pm 0,636$ \\
ESR, mm/ h & $60,53 \pm 0,817$ & $1,67 \pm 0,333$ \\
FA (30 min), \% & $2,33 \pm 0,333$ & $47 \pm 2,517^{*}$ \\
FI (30min), pcs. & $41,33 \pm 0,667$ & $0,8 \pm 0,018^{* * *}$ \\
CP, pcs & $0,65 \pm 0,024$ & $1,263 \pm 0,024^{*}$ \\
KM, pcs & $1,1 \pm 0,059$ & $2,71 \pm 0,331^{*}$ \\
T-I, \% & $2,0 \pm 0,033$ & $62 \pm 1 *$ \\
V-I, \% & $58,778 \pm 1,176$ & $28,667 \pm 1,333$ \\
T-I, 109/l & $27,267 \pm 0,504$ & $1,567 \pm 0,145^{*}$ \\
V-I, 109/l & $1,033 \pm 0,176$ & $0,81 \pm 0,08$ \\
T-I\%/ V-I\% & $0,733 \pm 0,12$ & $2,176 \pm 0,143$ \\
& $2,156 \pm 0,043$ & \\
\hline
\end{tabular}

Completion of phagocytosis (DF) was noted in animals of all groups, but higher rates were observed in the experimental groups. Studies have shown high, by $35 \%$ ( $p>0.05)$, indicators of the leukocyte mobilization coefficient. This indicates an increase in the activity of the micro-bicidal system of phagocytes in animals of these groups.
To characterize cellular and humoral immunity, a quantitative determination of $\mathrm{T}$ and B-lymphocytes was carried out.

Indicators of the cellular link of immunity of the 2nd and 3 rd experimental groups of rabbits were higher than the control. The absolute number of T-lymphocytes was higher by 27 and 52\% ( $p>0.05)$. The absolute number of B-lymphocytes showed an increase by 3 ( $p>$ 0.05 ) and $5 \%$, respectively, of the groups 
relative to the control. At the same time, the percentage of $\mathrm{T}$ - and B-lymphocytes in all groups in comparison with the background values did not change significantly.

\section{CONCLUSION}

Thus, based on the general analysis of studies of the morphological and immunological composition of blood, the advantage of the experimental groups was noted. The use of local probiotics has a hardening effect on the body of rabbits, which is manifested by the activation of the protective systems of the blood and an increase in the immune properties of animals.

\section{REFERENCES}

1. Берхоф П.К. Мелкие домашние животные. Болезни и лечение/ Пер. с нем. И. Кравец. Изд. 2, испр. и доп. М.: ООО "АКВАРИУМ ПРИНТ". - 2004.C.60.

2. Георгиевский В.И. Практическое руководство по физиологии сельскохозяйственных животных. Учеб. пособие для с.-х. вузов.- М., "Высш. школа",-1976.- С. 184-185.

3. Георгиевский В.И. Физиология сельскохозяйственных животных.- М.: Агропромиздат.- 1990. - 511 с.

4. Громыхина Н.Ю., Козлов В.А. Роль макрофагов во взаимодействии иммунной и эритроидной систем при формировании иммунного статуса. Иммунология.- 1997.- $\mathrm{N}^{\circ} 1 .-\mathrm{C.25-27.}$

5. Ефремов А.П., Мартынов П.Н. Интерьерные различия крольчат разного возраста/ Фундаментальные исследования. - 2012.- ํ⒌- С.138-141.

6. Иммунология. Под ред. Воронина Е.С. М.: Колос-Пресс, 2002.- 408 с.- С. 34.
7. Лакин Г.Ф. Биометрия. Учеб. пособие для биол. спец. вузов - 4-е ИЗД., перераб. и доп - М.: Высш. шк.- 1990.352 c.

8. Нагоев Б.С. Справочник по иммунологии. - Нальчик: Эльбрус, 2002 - 192 с. - С.53.

9. Ноздрин Г.А. Морфологические и биохимические показатели у кроликов при применении пробиотического препарата Велес 6.59/ Ноздрин ГА, Громова А.В. Иванова А.Б. и др.// Достижения науки и техники АПК.- $\mathrm{N}^{\circ}$ 10.- 2012.- C.53-55.

10. Омельченко Н.Н. Использование пробиотиков В профилактике болезней кроликов/ Омельченко Н.Н., Лысенко А.А., Омельченко Н.А., Остапчук А.В. // Труды Кубанского государственного аграрного университета.- $\mathrm{N}^{\circ}$ 53.- 2015.- С. 47.

11. Петрова Н.А. Влияние пробиотиков на показатели крови кроликов/ К.А. Сидорова, К.С. Есенбаева, Н.А. Петрова, А.А. Бекташева// Вестник Тюменской государственной сельскохозяйственной академии. Вып. 1. - Тюмень.- 2007. - С. 162-163.

12. Румина М.В. Зависимость иммунного ответа у кроликов от активности ферментов плазмы крови/ Румина М.В., Габалов К.П., Ласковый В.Н., Малинин М.Л.// Ветеринарная патология.- $\mathrm{N}^{\circ}$ 3.- 2013. - С. 72-77.

13. Сысоев В.С., Александров В.Н. Кролиководство.-М.: Агропромиздат, 1985. -272 C.

14. Титова А.В. Автореферат диссертации на соискание учёной степени кандидата биологических наук. Белково-аминокислотный состав крови и продуктивные качества кроликов при скармливании 
пробиотических репаратов. Орёл.2010.- 18 c.

15. Шакин А.А. Эффективность применения БиоПлюс 2Б в свиноводстве/ Эффективное животноводство.- $\mathrm{N}^{\circ}$ 3.- 2014.- С.34-35.

16. Miloslav Martinec, Helena Hartlova, Darina Chodova Eva Tumova Alena Fucfkova. Selected haematological and biochemical indicators in different breeds of rabbits. ACTA VET. BRNO 2012, 81: 371-375.

17. EFSA FEEDAP Panel (EFSA Panel on Additives and Products or Substances used in Animal Feed), 2012b. Guidance on the assessment of bacterial susceptibility to antimicrobials of human and veterinary importance. EFSA Journal 2012;10(6):2740, 10 pp. https://doi.org/10.2903/j.efsa.2012.2740

18. EFSA FEEDAP Panel (EFSA Panel on Additives and Products or Substances used in Animal Feed), 2013. Scientific Opinion on the safety and efficacy of Probiotic Lactina ${ }^{\circledR} \quad$ (Lactobacillus acidophilus, Lactobacillus helveticus, Lactobacillus bulgaricus, Lactobacillus lactis, Streptococcus thermophilus and Enterococcus faecium) for chickens for fattening and piglets. EFSA Journal 2013;11(4):3170, $13 \quad$ pp. https://doi.org/10.2903/j.efsa.2013. 3170. Available online: www.efsa.europa.eu/efsajournal 